\title{
Review
}

\section{An Overview of the Role of Long Non-Coding RNAs in Human Choriocarcinoma}

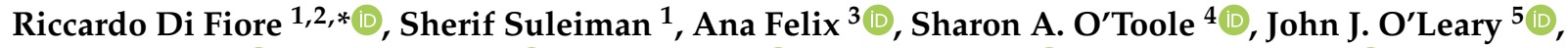

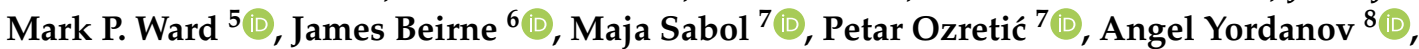 \\ Mariela Vasileva-Slaveva ${ }^{9}{ }^{\circledR}$, Stoyan Kostov ${ }^{10}{ }^{(}$, Margarita Nikolova ${ }^{11}$, Ian Said-Huntingford ${ }^{12}$,

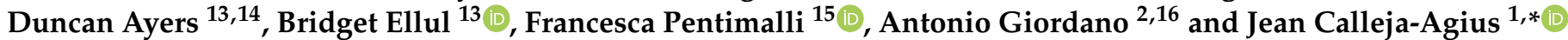

\section{check for} updates

Citation: Di Fiore, R.; Suleiman, S. Felix, A.; O'Toole, S.A.; O'Leary, J.J.; Ward, M.P.; Beirne, J.; Sabol, M.; Ozretić, P.; Yordanov, A.; et al. An Overview of the Role of Long Non-Coding RNAs in Human Choriocarcinoma. Int. J. Mol. Sci. 2021, 22, 6506. https://doi.org/ $10.3390 /$ ijms 22126506

Academic Editors: Damjan Glavač and Metka Ravnik-Glavač

Received: 27 April 2021

Accepted: 15 June 2021

Published: 17 June 2021

Publisher's Note: MDPI stays neutral with regard to jurisdictional claims in published maps and institutional affiliations.

Copyright: (C) 2021 by the authors Licensee MDPI, Basel, Switzerland. This article is an open access article distributed under the terms and conditions of the Creative Commons Attribution (CC BY) license (https:/ / creativecommons.org/licenses/by/ $4.0 /)$.
1 Department of Anatomy, Faculty of Medicine and Surgery, University of Malta, MSD 2080 Msida, Malta; sherif.s.suleiman@um.edu.mt

2 Center for Biotechnology, Sbarro Institute for Cancer Research and Molecular Medicine, College of Science and Technology, Temple University, Philadelphia, PA 19122, USA; president@shro.org

3 Department of Pathology, Campo dos Mártires da Pátria, Instituto Portugues de Oncologia de Lisboa, NOVA Medical School, UNL, 130, 1169-056 Lisboa, Portugal; ana.felix@nms.unl.pt

4 Departments of Obstetrics and Gynaecology and Histopathology, Trinity St James's Cancer Institute, Trinity College Dublin, 8 Dublin, Ireland; shotoole@tcd.ie

5 Department of Histopathology, Trinity College Dublin, Trinity St James's Cancer Institute, 8 Dublin, Ireland, olearyji@tcd.ie (J.J.O.); wardm6@tcd.ie (M.P.W.)

6 Department of Gynaecological Oncology, Trinity St James Cancer Institute, St James Hospital, 8 Dublin, Ireland; JBeirne@stjames.ie

7 Laboratory for Hereditary Cancer, Division of Molecular Medicine, Ruđer Bošković Institute, 10000 Zagreb, Croatia; maja.sabol@irb.hr (M.S.); pozretic@irb.hr (P.O.)

8 Department of Gynecologic Oncology, Medical University Pleven, 5800 Pleven, Bulgaria; angel.jordanov@gmail.com

9 Department of Surgery, Alexandrovska University Hospital, 1431 Sofia, Bulgaria; sscvasileva@gmail.com

10 Department of Gynecology, Medical University Varna "Prof. Dr. Paraskev Stoyanov", 9002 Varna, Bulgaria; drstoqn.kostov@gmail.com

11 Saint Marina University Hospital—Pleven, Medical University Pleven, 5800 Pleven, Bulgaria; mnikol@abv.bg

12 Department of Histopathology, Mater Dei Hospital, Birkirkara Bypass, MSD 2090 Msida, Malta; ian.said-huntingford@gov.mt

13 Centre for Molecular Medicine \& Biobanking, University of Malta, MSD 2080 Msida, Malta; Duncan.Ayers@um.edu.mt (D.A.); bridget.ellul@um.edu.mt (B.E.)

14 Faculty of Biology, Medicine and Human Sciences, The University of Manchester, Manchester M1 7DN, UK

15 Cell Biology and Biotherapy Unit, Istituto Nazionale Tumori-IRCCS-Fondazione G. Pascale, 80131 Napoli, Italy; f.pentimalli@istitutotumori.na.it

16 Department of Medical Biotechnologies, University of Siena, 53100 Siena, Italy

* Correspondence: riccardo.difiore@um.edu.mt (R.D.F.); jean.calleja-agius@um.edu.mt (J.C.-A.); Tel.: +356-2340-3871 (R.D.F.); +356-2340-1892 (J.C.-A.)

Abstract: Choriocarcinoma (CC), a subtype of trophoblastic disease, is a rare and highly aggressive neoplasm. There are two main CC subtypes: gestational and non-gestational, (so called when it develops as a component of a germ cell tumor or is related to a somatic mutation of a poorly differentiated carcinoma), each with very diverse biological activity. A therapeutic approach is highly effective in patients with early-stage CC. The advanced stage of the disease also has a good prognosis with around $95 \%$ of patients cured following chemotherapy. However, advancements in diagnosis and treatment are always needed to improve outcomes for patients with CC. Long non-coding (lnc) RNAs are non-coding transcripts that are longer than 200 nucleotides. LncRNAs can act as oncogenes or tumor suppressor genes. Deregulation of their expression has a key role in tumor development, angiogenesis, differentiation, migration, apoptosis, and proliferation. Furthermore, detection of cancer-associated lncRNAs in body fluids, such as blood, saliva, and urine of cancer patients, is emerging as a novel method for cancer diagnosis. Although there is evidence for the potential role of lncRNAs in a number of cancers of the female genital tract, their role in CC is poorly understood. This review summarizes the current knowledge of lncRNAs in gestational CC and how this may be applied to future therapeutic strategies in the treatment of this rare cancer. 
Keywords: choriocarcinoma; rare cancer; long non-coding RNA; oncogenes or tumor suppressor genes; lncRNA-based therapy

\section{Introduction}

Choriocarcinoma (CC), a subtype of trophoblastic disease [1], is a rare and highly aggressive tumor with varied global incidence [2]. CC is histologically characterized by an admixture of: syncytiotrophoblasts and mononucleated cytotrophoblastic cells. Two significant CC subtypes, gestational and non-gestational (so called when it develops as a component of a germ cell tumor or is related to a somatic mutation of a poorly differentiated carcinoma) (Figure 1), have diverse underlying biologies and clinical outcomes (Table 1) [3]. The former can arise in the uterus and rarely in extrauterine sites following a hydatidiform mole $(50 \%)$, a miscarriage or induced abortion $(25 \%)$, a normal pregnancy $(22.5 \%)$, or an ectopic pregnancy (2.5\%) [2]. Non-gestational CCs have been shown to arise from pluripotent germ cells in both male and female gonads, most commonly in the ovary and retroperitoneum [3-5], or pelvis [6]. Pure CC is exceedingly rare, but focal areas of CC are seen in approximately $12 \%$ of embryonal and teratocarcinomas [7]. Foci of CC may be present in gestational mixed trophoblastic tumors and in non-gestational mixed germ cell tumors. Rare cases of extrauterine carcinoma with trophoblastic cells represent differentiation of pluripotent cells into malignant somatic cells [3].
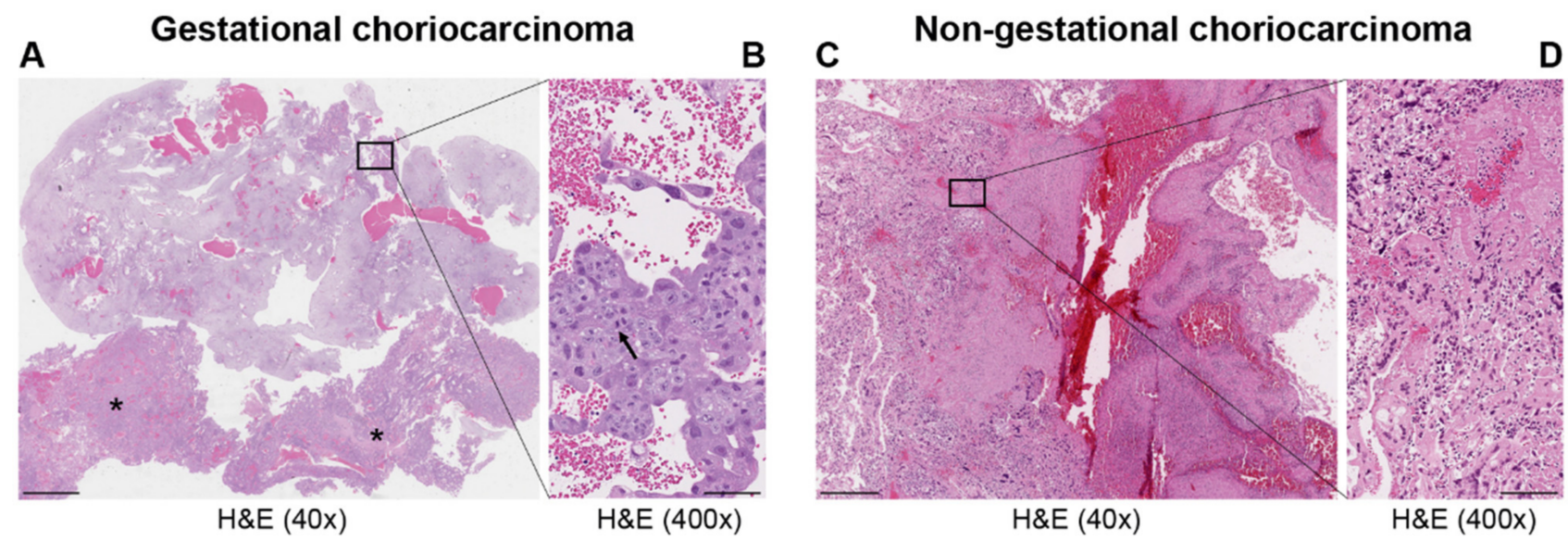

Figure 1. Representative images of hematoxylin and eosin (H\&E) staining in gestational (A,B) and non-gestational (C,D) choriocarcinoma. Uterine curettage $(\mathbf{A}, \mathbf{B})$; (A) low power $(40 \times$; scale bar $=500 \mu \mathrm{m})$ with abundant decidualized endometrium and blood and two large clusters of choriocarcinoma $(*)$; $(\mathbf{B})$ high power $(400 \times$; scale bar $=50 \mu \mathrm{m})$ shows aggregates of large trophoblasts with marked atypia and prominent mitotic figures (arrow) covered by atypical syncytiotrophoblasts. Invasive choriocarcinoma in the ovary $(\mathbf{C}, \mathbf{D})$. (C) Component of a germ cell tumor of the ovary with large and atypical trophloblastic cells with hemorrhage and necrosis (low power $40 \times$; scale bar $=500 \mu \mathrm{m}$ ) associated with dysgerminoma (not present in the picture). (D) Markedly atypical synciotrophoblasts and cytotrophoblasts (high power $400 \times$; scale bar $=50 \mu \mathrm{m})$.

As non-gestational CC has no specific genetic features but has a similar appearance to gestational CC without any of its special characteristics, hence, we will only focus on gestational CC, which has unique biological characteristics. 
Table 1. Summary of the features of choriocarcinoma-adapted from Cheung et al. [3].

\begin{tabular}{|c|c|c|c|}
\hline \multirow{2}{*}{ Types } & \multirow{2}{*}{ Gestational Choriocarcinoma } & \multicolumn{2}{|c|}{ Non-Gestational Choriocarcinoma } \\
\hline & & Germ Cell Tumor & Somatic Carcinoma \\
\hline Incidence & $\begin{array}{l}\text { Ranges from } 1 \text { in Europe to }-9.2 \text { in } \\
\text { Asia } / 40,000 \text { pregnancies }\end{array}$ & $\begin{array}{c}\text { Rare }<1 \% \text { of all ovarian tumors-children, } \\
\text { young adults but rarely in older adults. } \\
\text { Midline tumors mostly in males }\end{array}$ & Rare ovarian carcinomas in adults \\
\hline Origin & $\begin{array}{l}\text { It may develop as a complication of } \\
\text { pregnancy, usually following a } \\
\text { complete mole }\end{array}$ & It arises from primordial germ cells & $\begin{array}{l}\text { It arises from differentiation of } \\
\text { pluripotent cells into a } \\
\text { somatic carcinoma }\end{array}$ \\
\hline Site & $\begin{array}{l}\text { Primarily uterus and also intraplacental; } \\
\text { rarely ovary and extrauterine sites }\end{array}$ & $\begin{array}{l}\text { Gonads, midline: pineal gland, } \\
\text { mediastinum, retroperitonum }\end{array}$ & $\begin{array}{l}\text { Lung, gastrointestinal tract, and other } \\
\text { organs, including very rare ovarian } \\
\text { carcinoma and uterine cases in } \\
\text { post-menopause }\end{array}$ \\
\hline Histopathology & $\begin{array}{l}\text { Mononuclear cytotrophoblast and } \\
\text { intermediate trophoblast and multinucleated } \\
\text { syncytiotrophoblast cells with marked atypia } \\
\text { and mitoses }\end{array}$ & $\begin{array}{l}\text { Mainly in pure form with cyto- and } \\
\text { syncytiotrophoblast or with other } \\
\text { components of germ cell tumors (mixed } \\
\text { germ cell tumor) }\end{array}$ & $\begin{array}{c}\text { Presence hCC-producing } \\
\text { multinucleated giant cells; transition } \\
\text { with co-existing somatic carcinoma of } \\
\text { the particular organ }\end{array}$ \\
\hline Cytogenetic features & $\begin{array}{l}\text { Deletion of 7p12-7q11.2; amplification of } \\
\text { 7q21-q31 and loss of 8p12-21 [3] }\end{array}$ & Gain of $12 p[3]$ & Unknown \\
\hline Biochemical features & hCG in serum or urine $\left(>10 \times 10^{3} \mathrm{mlU} / \mathrm{mL}^{)}\right.$ & hCG in serum or urine & hCG in serum or urine-variable \\
\hline Molecular markers & $\begin{array}{c}\text { Upregulation of TP53, CDKN1A, RB1, EGFR, } \\
\text { ERBB2, c-M YC, BCL2, NANOG, H19 [3,8]; } \\
\text { Downregulation of NECC1, TIMP3, } \\
\text { DOC-2/hDab2, RASSF1A, CDKN2A, CDH1, } \\
\text { IGF2, OCT4, SOX2 [3,8]; } \\
\text { Mutated genes: NLRP7, ARID1A, SMARCD1, } \\
\text { EP300 [9] }\end{array}$ & $\begin{array}{c}\text { Upregulation of CGB5, CGA, NANOG, } \\
\text { STELLA, GDF3 [3] }\end{array}$ & Upregulation of NANOG [3] \\
\hline Treatment & Chemotherapy & $\begin{array}{l}\text { Surgery is indicated. Chemotherapy of } \\
\text { different drug regimens is applied }\end{array}$ & $\begin{array}{l}\text { Surgery is indicated. May respond to } \\
\text { chemotherapy but it may not be useful }\end{array}$ \\
\hline Prognosis & Good & Poor & Poor \\
\hline
\end{tabular}

To date, little is known regarding the underlying pathophysiology and oncogenesis in this malignancy. Gestational CC is likely to arise as a result of aberrations of methylation during development, rather than from DNA mutations, supporting the hypothesis that it arises from normally transient early trophoblast cells [10]. At a molecular level, gestational $\mathrm{CC}$ is also characterized by an overexpression of TP53, MDM2, and epidermal growth factor receptor (EGFR), and downregulation of a number of genes, including NECC1, DOC2/hDab2, KRAS, CDH1, CDKN2A, HIC-1, and TIMP3 [8]. Other oncoproteins (BCL-2, c-FMS, c-ERB-2, and c-MYC) exhibiting synergistic upregulation have also been implicated in the pathogenesis of CC [8]. Moreover, elevated levels of human leucocyte antigen-G (HLA-G) in CC may inactivate the local immune system, thus altering the tumor microenvironment as well as promoting proliferative and metastatic capability of the tumor [8]. Jung et al. detected driver mutations in gestational $\mathrm{CC}$, most of which were chromatin remodeling gene mutations (ARID1A, SMARCD1, and EP300) [9]. A heterozygous germline mutation was also found in the NLRP7 gene, which has been studied extensively in relation to gestational trophoblastic disease, with mutations of this gene having been reported in 50\% of complete hydatidiform moles with high risk of evolving to CC [11]. Moreover, NLRP7 has been shown to be involved in placental development by demonstrating its effects on trophoblast proliferation, differentiation, migration, invasion, and apoptosis [12].

A therapeutic approach is highly effective in patients with early-stage $\mathrm{CC}$, and the advanced stage of the disease also has a good prognosis, with around $95 \%$ of patients being cured with chemotherapy. However, advances in diagnosis and treatment are always needed to improve outcomes for patients with CC [13]. 
Although the vast majority of the human genome is transcribed, only $2 \%$ of all the transcribed genes are protein-coding genes. There has been speculation over the role of noncoding RNA (ncRNA), ranging from junk transcripts to master epigenetic regulators. Long non-coding RNAs (lncRNAs) are a particular class of ncRNAs that have been increasingly recognized as having a fundamental regulatory role in both health and disease [14-17]. LncRNA transcripts are involved in transcriptional regulation, subcellular localization, and epigenetic remodeling. Dysregulated lncRNAs have been associated with cancer through either up- or downregulation of specific lncRNAs occurring relative to the adjacent normal tissue [18]. Therefore, these lncRNAs behave like oncogenes or tumor suppressor genes. For instance, overexpression of the HOTAIR lncRNA correlates with cancers that are more aggressive [19-25], whereas MEG3 lncRNA may act as a tumor suppressor and its downregulation has been associated with the development of a variety of human cancer involving the liver, breast, uterus, and ovary [26]. LncRNAs can also contribute to the cellular fate programs in cancer stem cells, which are involved in tumorigenesis and therapy resistance [27]. OCT4 is a stemness-related transcription factor, which regulates the expression of both the lncRNAs NEAT1 and MALAT1 to promote the progress of lung cancer [28]. Moreover, NEAT1 leads to stem-like phenotypes in NSCLC, TNBC, and GBM cells [29-31]. The lncRNA B4GALT1-AS1 recruits the yes-associated protein (YAP) to the nucleus, a potent oncogene related to several oncogenic programs, including stemness. This enhances its transcriptional activity, thus further promoting stemness in colon cancer cells [32,33]. Another example has been shown in glioma, where the lncRNA SNHG20 enhances stemness by activating the PI3K/Akt/mTOR signaling pathway [34].

Detection of lncRNAs associated with cancer in body fluids (i.e., blood, saliva, urine, etc.) is a valuable method not only for more effective cancer diagnosis, but possibly also for earlier detection of cancers and for use as therapeutic targets. Furthermore, using body fluids to detect circulating lncRNAs is much less invasive when compared to collecting biopsies [35].

Recently, Hosseini et al. published a comprehensive overview on the potential roles of lncRNAs in several cancers of the female reproductive system [36]. However, their role in $\mathrm{CC}$ is relatively poorly established. In this review, we summarize the current knowledge of lncRNA function and how this may be applied to future therapeutic strategies, specifically in the management of gestational CC.

\section{Biological Characteristics of LncRNAs and Their Molecular Functions}

LncRNAs are regulatory transcripts that are over 200 nucleotides long. These are mainly transcribed by RNA polymerase II, typically by a $5^{\prime} 7$-methylguanosine cap and a $3^{\prime}$ poly (A) tail similar to messenger RNAs [37]. Non-coding transcripts ( $>200$ nucleotides) which are generated from introns, exons, intergenic regions, telomeres, enhancers, or promoters are considered as different classes of lncRNAs (Table 2) [38-42]. Characteristically, lncRNAs are able to shuttle to numerous subcellular locations. There are very different levels of accumulation in the nucleus of certain lncRNAs when compared to cytoplasmic levels, while there is equal distribution for other lncRNAs [43]. LncRNAs are cell type dependent and the precise number of lncRNAs generated from the human genome is estimated to be very high (tens of thousands and up to more than one hundred thousand transcripts) [44,45]. Although most of these transcripts have not been studied, there is evidence that lncRNAs are able to regulate gene expression networks via the control of nuclear architecture and transcription in the nucleus, as well as the modulation of mRNA stability, together with translation and post-translational modifications in the cytoplasm [46]. This occurs mainly using four functional modes of action (Table 3) [47-54]. 
Table 2. Classification of lncRNAs.

\begin{tabular}{ccc}
\hline Genomic Location & Description & Example \\
\hline Intergenic & $\begin{array}{c}\text { transcripts originated from intergenic loci; that is, located } \\
\text { between two protein-coding genes }\end{array}$ & XIST, NEAT1, PANDAR, BGLT3 \\
\hline Intronic & transcripts originated from introns of protein-coding genes & NDM29, IRAIN, EGOT \\
\hline Sense & $\begin{array}{c}\text { transcripts originated from the sense strand of } \\
\text { protein-coding genes, containing exons from } \\
\text { protein-coding genes }\end{array}$ & SNHG3, SRA, RUNXOR \\
\hline Antisense & $\begin{array}{c}\text { transcripts originated from the antisense strand of } \\
\text { protein-coding genes }\end{array}$ & SNHG6, HOXA-AS2, ZEB2-AS1 \\
\hline Enhancer & $\begin{array}{c}\text { transcripts, found in both polyadenylated or } \\
\text { non-polyadenylated forms, bi-directionally expressed at } \\
\text { active enhancer regions of the genome }\end{array}$ & DLX6-AS1, Alpha-250/Alpha-280, \\
\hline Promoter & $\begin{array}{c}\text { transcripts derived from gene promoter regions in the } \\
\text { opposite direction to the paired coding RNA }\end{array}$ & DBET, pancIl17d, HIF2PUT \\
\hline
\end{tabular}

Table 3. Molecular functions of lncRNAs.

\begin{tabular}{|c|c|c|c|}
\hline Mechanism Type & Mode of Function & Examples & Reference \\
\hline Signal & $\begin{array}{l}\text { Serves as a molecular signal to } \\
\text { reflect development or disease } \\
\text { status }\end{array}$ & $\begin{array}{l}\text { XIST is typically transcribed by the inactive } \\
\mathrm{X} \text { chromosome; can be used to indicate } \mathrm{X} \\
\text { chromosome inactivation }\end{array}$ & {$[47,48]$} \\
\hline Decoy & $\begin{array}{l}\text { Sequestering regulatory factors } \\
\text { (transcription factors, chromatin } \\
\text { modifiers, miRNAs, etc.) } \\
\text { modulate transcription }\end{array}$ & $\begin{array}{c}\text { PANDAR inhibits proptosis by directly } \\
\text { sequestering NF-YA. H19 acts as ceRNAs * } \\
\text { both for miR-17-5p in thyroid cancer and for } \\
\text { miR-152 in breast cancer }\end{array}$ & [49-51] \\
\hline Guide & $\begin{array}{l}\text { Essential for the proper } \\
\text { localization of proteins to their } \\
\text { site-specific reaction }\end{array}$ & $\begin{array}{l}\text { MEG3 guides PRC2 and forms a complex } \\
\text { with DNA }\end{array}$ & [52] \\
\hline Scaffold & $\begin{array}{l}\text { Provides platforms to assist in } \\
\text { the assembly of regulatory } \\
\text { complexes }\end{array}$ & $\begin{array}{c}\text { HOTAIR interacts with polycomb repressive } \\
\text { complex } 2 \text { (PRC2) to recruit EZH2 to } \\
\text { promote H3K27 trimethylation or LSD1 to } \\
\text { demethylate H3K4me2 }\end{array}$ & {$[53,54]$} \\
\hline
\end{tabular}

At the molecular level, the production of lncRNAs can act as a "signal" in response to a significant biological event, such as DNA damage. LncRNA transcripts can also regulate downstream functions that are related to other functional models. LncRNAs may also behave as a "decoy" through interaction with proteins and/or other RNA molecules, directly interfering with protein/genomic DNA, protein-protein, or RNA-RNA interactions. The decoy function of lncRNAs may sequester miRNA, preventing miRNA-mediated silencing of target mRNA. This is known as the miRNA sponging effect by lncRNAs. In addition, lncRNAs can serve as "guides" facilitating the recruitment of protein complexes to genomic loci. The lncRNA "scaffolds" act as the nucleation point, leading to the formation of protein complexes, or else mediate interaction between the different protein complexes [55]. Additionally, lncRNAs are involved in cancer chemoresistance [56,57].

\section{Dysregulated lncRNAs in Choriocarcinoma}

LncRNAs are crucial molecules in different biological processes and play an integral part in gene expression and its regulation. While there is still a lack of understanding of the function of lncRNAs, there is evidence that they are involved in the initiation and progression of a number of cancers [58,59]. LncRNAs, by acting as tumor suppressor genes or oncogenes, play a critical physiological role in apoptosis, invasion, metastasis, and cell proliferation in several cancers. LncRNAs are also involved in the pathogenesis of cancers of the female reproductive system (ovarian, uterine, vaginal, cervical, and vulvar cancers) [36]. However, to date, only a few studies address the role of lncRNA in CC. Novel mechanistic insights into how gene expression is specifically regulated by lncRNAs, contributing to CC formation, are outlined below. Table 4 summarizes the functions of the main lncRNAs implicated in CC. 
Table 4. LncRNAs with a role in choriocarcinoma.

\begin{tabular}{|c|c|c|c|c|c|}
\hline LncRNA & Locus & Role & $\begin{array}{l}\text { Molecular } \\
\text { Functions }\end{array}$ & Target Pathway & Sources \\
\hline MALAT1 & 11q13.1 & Oncogene & Sponge of miR-218 & Unknown & $\begin{array}{l}\text { Three CC cell lines, JEG-3, JAR, and BeWo cells, and a } \\
\text { normal cell line human trophoblast cells (HT cells) [60] }\end{array}$ \\
\hline$H 19$ & $11 \mathrm{p} 15.5$ & Oncogene & Unknown & PI3K/AKT/mTOR [61] & $\begin{array}{c}\text { Placenta, androgenetic moles, and choriocarcinoma [62]; } \\
\text { CC cell line JEG-3, including MTX- and 5-FU-resistant } \\
\text { variants [61] }\end{array}$ \\
\hline MEG3 & $14 q 32.3$ & $\begin{array}{c}\text { Tumor } \\
\text { suppressor }\end{array}$ & Unknown & Unknown & $\begin{array}{l}\text { Placenta; } 4 \text { cell-lines associated with pregnancy, } \\
\text { including HTR-8/SVneo, JEG-3, WISH, and HUVEC [63] }\end{array}$ \\
\hline PCA3 & $9 q 21-22$ & Oncogene & $\begin{array}{l}\text { Sponge of } \\
\text { miR-106b }\end{array}$ & Unknown & $\begin{array}{l}\text { Three CC cell lines, JAR, BeWo, and JEG-3, and the } \\
\text { human chorionic trophoblast cell HTR-8 [64] }\end{array}$ \\
\hline LINC00261 & 20p11.21 & $\begin{array}{l}\text { Tumor } \\
\text { suppressor }\end{array}$ & Unknown & Unknown & $\begin{array}{l}\text { Sixty CC tissues and } 60 \text { adjacent non-cancerous tissues; } 3 \\
\text { CC cell lines, namely, BeWo CCL-98, JEG-3, and JAR [65] }\end{array}$ \\
\hline OGFRP1 & $22 q 13.2$ & Oncogene & Unknown & $\mathrm{AKT} / \mathrm{mTOR}$ & Two CC cell lines, JEG-3 and JAR [66] \\
\hline $\begin{array}{l}\text { MIR503HG and } \\
\text { LINC00629 }\end{array}$ & Xq26 & $\begin{array}{l}\text { Tumor } \\
\text { suppressor }\end{array}$ & Unknown & Unknown & $\begin{array}{l}\text { RNA samples from a commercial normal human tissue } \\
\text { panel and } 18 \text { cancer cell lines, JEG-3 cell line [67] }\end{array}$ \\
\hline
\end{tabular}

\subsection{MALAT1}

Metastasis-associated lung adenocarcinoma transcript 1 (MALAT1), or, as it is also known, non-coding nuclear-enriched abundant transcript 2 (NEAT2), is a lncRNA which is $8000 \mathrm{nt}$ long and is located on chr11q13.1 [68]. It has been shown to be involved in several physiological regulatory processes, including nuclear organization, epigenetic modification of gene expression, and alternative splicing via the modulation of phosphorylation of the SR splicing factor. It is also directly related to various pathological processes in non-communicable diseases, such as diabetes, and even in cancer [69]. The upregulation of MALAT1 has been observed in different cancer types, including endometrial and cervical cancer, where there is an association with increased tumorigenesis and reduced survival [70-72]. In gastric cancer, it has been demonstrated that MALAT1 can enhance SOX2 mRNA stability, thus promoting stemness in cancer cells [27]. In CC, MALAT1 might also promote tumor growth via miR-218-mediated FBXW8 regulation [60]. This suggests that it could be therapeutically targeted in human CC.

\section{2. $H 19$}

H19 is a paternally imprinted gene, which encodes a $2300 \mathrm{nt}$ long lncRNA. It is located on chromosome 11p15.5 and was identified from the transcription of the H19/insulin-like factor 2 gene cluster $[73,74]$. It has been shown that $H 19$ is upregulated only during the early stages of embryogenesis, and is downregulated after birth [75]. Hao et al. suggested that $H 19$ may act as a tumor suppressor gene [76], however, other studies reported an increased expression in several cancers [77,78]. H19 regulates the expression of some cancer-related proteins, such as the ubiquitin ligase E3 family, calneuron 1 and retinoblastoma tumor suppressor (RB1) [79], and alpha-4, beta-3, and beta-5 integrins [80]. The dysregulation of H19 in gynecological cancers (ovarian, endometrial, and cervical cancer) is associated with several molecular pathways that are normally disrupted in cancer [36]. In CC, there is an abnormal expression of $H 19$ where it plays an important role in tumor development [62]. Yu et al. investigated the role of H19 in CC cells which are resistant to drugs and demonstrated that H19, through the regulation of the PI3K/AKT/mTOR pathway, results in drug resistance together with increased proliferative, migratory, and invasive ability of CC cells [61]. This suggests H19 may be a potential therapeutic target for the treatment of drug-resistant CC.

\subsection{MEG3}

Maternally expressed gene 3 (MEG3) is a lncRNA which is $1600 \mathrm{nt}$ long. It is located at the locus of DLK1-MEG3 on human chromosome 14q32.3 [81]. MEG3 is ubiquitously expressed in normal tissue and loss of its expression has been reported in various cancers, suggesting MEG3 can behave as a tumor suppressor. When compared to normal tissue, 
there is a decreased expression of $M E G 3$ in ovarian cancer. MEG3 overexpression causes anti-proliferative and cytotoxic effects in the OVCAR3 ovarian cancer cell line [26,81]. Likewise, MEG3 is also downregulated in cervical cancer when compared to the adjacent normal tissues, and there is a negative correlation with tumor size, FIGO stage, lymphatic metastases, infection with human papilloma virus (HPV), and miR-21 expression [82]. Furthermore, cervical cancer cells undergo increased apoptosis and growth suppression after $M E G 3$ upregulation, confirming its role in tumor suppression in this type of cancer. Zhang et al. reported that CC progression in the human JEG-3 cell line was directly linked to a reduction in $M E G 3$ levels [63].

\subsection{PCA3}

Prostate cancer antigen $3(P C A 3)$ is a lncRNA that is located on chromosome 9q21-22 in the antisense direction in intron 6 of the prune homolog 2 gene (PRUNE2 or BMCC1) [83]. $P C A 3$ is significantly upregulated in prostate cancer [84,85]. Increased expression of $P C A 3$ increases the proliferative, invasive, and migratory ability of prostate cancer cells and it is currently used as a diagnostic tool in managing prostate cancer [86,87]. Quek et al. also found increased expression of $P C A 3$ in epithelial ovarian cancer [88]. The expression of $P C A 3$ is upregulated in CC cells [64]. Furthermore, through sponging miR-106b, $P C A 3$ promotes the expression of MMP2, thus facilitating the proliferation, invasion, migration, and epithelial-mesenchymal transition of CC cells in vitro, suggesting that PCA3 may contribute to the progression of CC by acting as a competitive endogenous RNA (ceRNA) against miR-106b.

\subsection{LINC00261}

The long intergenic non-coding RNA 00261 (LINC00261) is a lncRNA located on chromosome 20p11.21. Initially, it was found to be differentially expressed in pancreatic and gastric cancers [89,90]. Repression of LINC00261 results in increased cell proliferation, invasion, migration, and chemoresistance in multiple cancers. This suggests that it plays a tumor suppressor role [91-93]. LINC00261 is downregulated in both CC tissues and cell lines [65]. Furthermore, overexpression of LINC00261 causes a reduction in cell proliferation, migration, and invasion, and promotes apoptosis in CC JEG-3 and JAR cells. These findings highlight that LINC00261 may play an important role in the early diagnosis and management of CC.

\subsection{OGFRP1}

Long non-coding RNA OGFRP1 (OGFRP1) is a novel lncRNA located on chromosome 22q13.2, and is involved in autophagy regulation in human coronary artery endothelial cells (HCAECs) [94]. It also plays a regulatory role in the proliferative and invasive capacity of various hepatocellular carcinoma (HCC) cell lines, albeit with varying effects in different HCC cell lines [95]. Increased expression of OGFRP1 has been reported in cervical cancer with subsequent silencing, resulting in the loss of proliferative and invasive capacities of cervical carcinoma cells [96]. These results suggest that in cervical carcinoma, OGFRP1 might display oncogenic properties. The oncogenic role of OGFRP1 in CC cells was recently reported by Meng and Xue [66]. Downregulation of OGFRP1 inhibited cell cycle progression, proliferation, and invasion of JEG-3 and JAR cells and also induced apoptosis through the AKT/mTOR pathway. Even though further research is required to fully understand the role OGFRP1 plays in tumorigenesis, it appears that OGFRP1 may be an important therapeutic target in CC.

\subsection{MIR503HG and LINC00629}

MIR503HG and LINC00629 genes, described as long intergenic non-coding RNAs (lincRNAs), are located on Xq26. The same region contains other genes, which are related to the reproductive system, and fetal/placental development [97,98]. Whilst MIR503HG 
expression appears to be restricted to the placenta, LINC00629 is highly expressed in the placenta as well as reproductive organs [67].

Analysis of RNA-sequencing data sets in colorectal cancer tissues showed an upregulation of MIR503HG [99]. Moreover, Chung et al. found that MIR503HG is one of the top five non-coding genes, with high levels of expression in anaplastic large-cell lymphoma [100]. In contrast, MIR503HG is downregulated in hepatocellular carcinoma [101] and oral squamous cell carcinoma [102]. Fu et al. showed that MIR503HG suppresses cell invasion and migration via the miR-103/OLFM4 axis in TNBC [103].

LINC00629 is downregulated in gastric cancer and RNA LINC00629 suppresses the progression of this cancer through the upregulation of AQP4, via the competitive binding to miR-196b-5p [104]. Together with MIR503HG2, several LINC00629 isoforms restrain the migration and invasion potential of the JEG-3 tumor cell line. This indicates a potential role for MIR503HG and LINC00629 in tumorigenesis involving the human reproductive system.

From a treatment perspective, the presence of $\mathrm{CpG}$ islands in the promotor regions of both lincRNAs is very interesting since the silencing of promoter regions by DNA methylation is typical of cancer and the subsequent reactivation with DNA demethylating agents could be important in CC treatment. In this regard, Muys et al. demonstrated that overexpression of MIR503HG2 together with the three new exon LINC00629 isoforms decreases the migration and invasion potential of the JEG-3 cell line, indicating a possible role for MIR503HG and LINC00629 in CC therapy [67].

\section{Clinical Applications of lncRNAs in Choriocarcinoma}

Given that lncRNAs can be detected in almost all tissues and body fluids, including peripheral blood, and are not easily degraded by RNases, they can be more sensitive and specific than DNA, proteins, and protein-coding RNAs in the diagnosis of tumors $[105,106]$. Thus, lncRNAs can be potentially utilized as novel non-invasive biomarkers in cancer diagnosis [107]. Even though there has been increasing interest in the study of lncRNAs in gynecological cancers, research is still preliminary. The association of many dysregulated lncRNAs with clinical features leads to the design of novel biomarkers for diagnosis and management of patients with gynecological cancers, ultimately attaining better prognosis [36]. Whether lncRNAs will be also beneficial in the early detection of CC needs to be investigated. Currently, there is no evidence that lncRNAs are used as biomarkers for diagnosis and prognosis of patients with CC. Moreover, given the rarity of the tumor, we hope that these molecules may be used in the future to distinguish gestational CC from non-gestational tumors in an easier and quicker way than the current state-of-the-art methods (biopsy and microsatellite analysis).

\section{LncRNAs as Therapeutic Targets}

LncRNA transcripts have been described as architectural RNAs, molecular scaffolds, and can function as regulatory molecules. They are involved in epigenetic modification, post-transcriptional regulation, mRNA stability, and translation. They may also act as "sponges" for mature miRNAs, whereby they inhibit their activity [108]. Interestingly, most lncRNAs are expressed in a cell type- and tissue-specific manner, and in this respect, lncRNAs lend themselves as potentially important therapeutic targets. Specifically, lncRNA targeted therapy, unlike chemotherapeutic regimens, needs to hinder the signaling pathways in which lncRNA plays an important role in tumor development and progression, whilst aiming to avoid the adverse effects on normal cells. There may also be a potential role of lncRNA as biomarkers for disease management, including non-invasive screening [109].

Recent advances utilize CRISPR technology and oligonucleotide-based therapy to modify gene expression. These approaches may be pivotal for developing novel therapeutic approaches aiming at interfering with oncogenic lncRNAs [110].

The use of RNA interference (RNAi) to modulate gene expression has been successfully used to silence lncRNA in vivo [111]. Advancements in RNAi have led to Food and Drug Administration (FDA) approval of lipid nanoparticles (LNPs) which contain short 
interfering RNA (siRNA) that is being used to treat hereditary amyloidosis in adults [112]. However, to successfully modulate lncRNA, prior knowledge of lncRNA cellular localization is required. Furthermore, successful implementation requires ensuring that the interfering molecules are stable and, most importantly, their immunogenicity and toxicity is minimal. To ensure stability and avoid enzymatic degradation of RNAi drugs, two modifications have been successfully carried out involving the phosphorothioate backbone [113] and the 2'-O-methyl sugar [114].

LncRNAs associated with cancer can also be modulated by using antisense oligonucleotides (ASOs). ASOs are single stranded with a central native or chemically modified DNA stretch, flanked on either side by RNA nucleotides. DNA forms RNA/DNA heteroduplex with target lncRNA, which is cleaved by endogenous RNaseH1 [115]. ASOs have been successfully used to alter mRNA expression as part of the treatment of various diseases, including different types of cancer where lncRNAs are highly expressed [116,117]. Various designs of ASOs are utilized via diverse modes of action, including antagonist to NATs (antagoNAT), locked nucleic acid GapmeRs (LNAGapmeRs), and mixmers.

Advances in genomic interference methods, with superior specificity when compared to RNAi, have been developed recently. CRISPR interference (CRISPRi) using CRISPR-Cas9 and CRISPR-Cas13 led to the successful silencing of transcriptionally active lncRNA-expressing sites. In the CRISPR-Cas9 approach, nucleotides devoid of nucleolytic activity, termed dead-Cas9, are fused to transcriptional repressors. Transcriptional silencing is achieved because, via guide RNAs, this fusion protein is targeted to a specific gene promoter [118]. The development of guide RNAs targeting the promoters of thousands of IncRNAs in the human genome together with CRISPRi enabled the selective inactivation of lncRNA genes in human cancer cell lines. Liu et al. further underscored tissue specificity of lncRNA by identifying approximately 500 lncRNAs in only one cell type [119]. Therefore, it is possible to achieve transcriptional silencing of lncRNAs via CRISPR-based approaches, however, several challenges limit their immediate use for therapeutic targeting [120-123]. Major limitations include delivery methods (viral and non-viral vectors), with viral vectors limited in the size of the cargo they are able to deliver to the cells of interest [124-127]. Regardless of the current limitations, the future undoubtedly looks bright for CRISPR-directed lncRNA therapies.

\section{Future Directions and Conclusions}

LncRNAs acting as tumor biomarkers have been shown to have an important role in the diagnosis and management of a number of cancers. Studies on the relationship between lncRNAs and gynecological cancer are still at the preliminary stages. Even though different lncRNAs seem to have oncogenic or tumor suppressive roles in CC (Figure 2), the exact underlying molecular mechanism of lncRNAs in CC is largely unknown. A number of lncRNAs could be associated with tumorigeneses, invasion, and stemness, leading to therapy resistance in CC. Currently, research is still in the early stages of characterizing the wide range of roles lncRNAs may play in CC pathogenesis. Therefore, more detailed investigation of lncRNAs in CC is needed. This may revolutionize our understanding of CC and result in advances in management, beyond the state of the art. In this regard, molecular tools including ASOs, siRNAs, and CRISPR technology could be used in the future development of RNA-based therapeutics targeting oncogenic lncRNAs. 


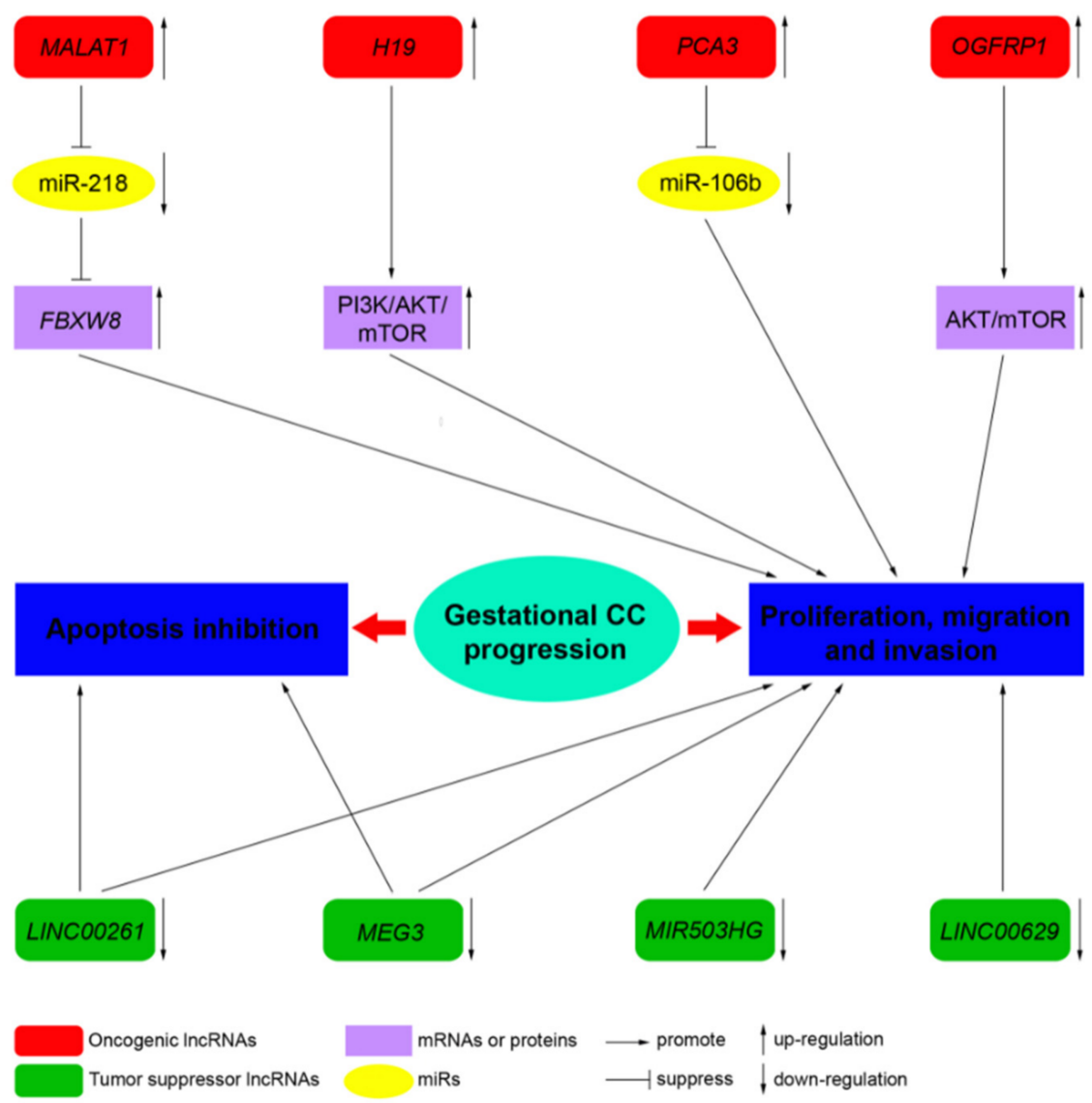

Figure 2. Long non-coding RNAs (lncRNAs) mediate various biological processes to regulate the progression of gestational CC. Certain representative lncRNAs function as oncogenes or tumor suppressors in specific biological processes of gestational CC.

Author Contributions: Conceptualization, R.D.F. and J.C.-A.; writing-original draft preparation, R.D.F. and J.C.-A.; writing-review and editing, R.D.F., S.S., A.F., S.A.O., J.J.O., M.P.W., J.B., M.S., P.O., A.Y., M.V.-S., S.K., M.N., I.S.-H., D.A., B.E., F.P., A.G., and J.C.-A.; funding acquisition, J.C.-A. All authors have read and agreed to the published version of the manuscript.

Funding: The publication of this manuscript was funded by the European Cooperation in Science \& Technology Program (EU COST)-COST Action CA18117: GYNOCARE- "European network for Gynaecological Rare Cancer research: From Concept to Cure". R.D.F., S.S., A.F., S.A.O., J.J.O., M.P.W., J.B., M.S., P.O., A.Y., M.V.-S., B.E., A.G., and J.C.-A. are Action management committee members and/or form part of Working Groups 1-3, and J.C.-A. is the Chairperson of this Action.

Institutional Review Board Statement: Not applicable.

Informed Consent Statement: Not applicable.

Data Availability Statement: Not applicable.

Conflicts of Interest: The authors declare no conflict of interest.

\section{Abbreviations}

ASO

Cas

$\mathrm{CC}$

CeRNA

CRISPR

CRISPRi antisense oligonucleotide

CRISPR-associated

choriocarcinoma

competitive endogenous RNA

clustered regularly interspaced short palindromic repeats

CRISPR interference 


$\begin{array}{ll}\text { FIGO } & \begin{array}{l}\text { Fédération Internationale de Gynécologie et d'Obstétrique } \\ \text { GBM }\end{array} \\ \text { glioblastoma multiforme } \\ \text { human papillomavirus } \\ \text { LINC00261 } & \text { long intergenic non-coding RNA 00261 } \\ \text { LncRNA } & \text { long non-coding RNA } \\ \text { LNAGapmeRs } & \text { locked nucleic acid GapmeRs } \\ \text { MALAT1 } & \text { metastasis-associated lung adenocarcinoma transcript } 1 \\ \text { MEG3 } & \text { maternally expressed gene } \\ \text { NATs } & \text { natural antisense transcripts } \\ \text { ncRNA } & \text { non-coding RNA } \\ \text { NEAT1/2 } & \text { non-coding nuclear-enriched abundant transcript } \frac{1}{2} \\ \text { NSCLC } & \text { non-small-cell lung carcinoma } \\ \text { OGFRP156 } & \text { opioid growth factor receptor pseudogene } 1 \\ \text { PCA3 } & \text { prostate cancer antigen 3 } \\ \text { RNAi } & \text { RNA interference } \\ \text { siRNAs } & \text { small interfering RNAs } \\ \text { TNBC } & \text { triple-negative breast cancer }\end{array}$

\section{References}

1. Bruce, S.; Sorosky, J. Gestational Trophoblastic Disease. In StatPearls; StatPearls Publishing: Treasure Island, FL, USA, 2021. Available online: https:/ / www.ncbi.nlm.nih.gov/books/NBK470267 (accessed on 18 February 2021).

2. Lurain, J.R. Gestational trophoblastic disease I: Epidemiology, pathology, clinical presentation and diagnosis of gestational trophoblastic disease, and management of hydatidiform mole. Am. J. Obstet. Gynecol. 2010, 203, 531-539. [CrossRef] [PubMed]

3. Cheung, A.N.; Zhang, H.J.; Xue, W.C.; Siu, M.K. Pathogenesis of choriocarcinoma: Clinical, genetic and stem cell perspectives. Future Oncol. 2009, 5, 217-231. [CrossRef] [PubMed]

4. Stockton, L.; Green, E.; Kaur, B.; de Winton, E. Non-Gestational Choriocarcinoma with Widespread Metastases Presenting with Type 1 Respiratory Failure in a 39-Year-Old Female: Case Report and Review of the Literature. Case Rep. Oncol. 2018, 11, 151-158. [CrossRef] [PubMed]

5. WHO. Classification of tumors editoral board. Female genital tumors. In WHO Classification of Tumors Series, 5th ed.; IARC: Lyon, France, 2020; Volume 4, Available online: https: / / publications.iarc.fr/592 (accessed on 20 December 2020).

6. Zhang, X.; Yan, K.; Chen, J.; Xie, X. Using short tandem repeat analysis for choriocarcinoma diagnosis: A case series. Diagn. Pathol. 2019, 14, 93. [CrossRef] [PubMed]

7. Friedlander, T.W.; Ryan, C.J.; Small, E.J.; Torti, F. Testicular cancer. In Abeloff's Clinical Oncology, 5th ed.; Niederhuber, J.E., Armitage, J.O., Doroshow, J.H., Kastan, M.B., Tepper, J.E., Eds.; Elsevier Saunders: Philadelphia, PA, USA, 2014; Chapter 86; pp. 1507-1533.

8. Shih, I.-M. Gestational trophoblastic neoplasia-Pathogenesis and potential therapeutic targets. Lancet Oncol. 2007, 8, 642-650. [CrossRef]

9. Jung, S.H.; Choi, Y.J.; Kim, M.S.; Park, H.C.; Han, M.R.; Hur, S.Y.; Lee, A.W.; Shin, O.R.; Kim, J.; Lee, S.H. Distinct genomic profiles of gestational choriocarcinoma, a unique cancer of pregnant tissues. Exp. Mol. Med. 2020, 52, 2046-2054. [CrossRef]

10. Savage, P.; Monk, D.; Hernandez Mora, J.R.; van der Westhuizen, N.; Rauw, J.; Tinker, A.; Robinson, W.; Song, Q.; Seckl, M.J.; Fisher, R.A. A case of intraplacental gestational choriocarcinoma; characterised by the methylation pattern of the early placenta and an absence of driver mutations. BMC Cancer 2019, 19, 744. [CrossRef]

11. Sills, E.S.; Obregon-Tito, A.J.; Gao, H.; McWilliams, T.K.; Gordon, A.T.; Adams, C.A.; Slim, R. Pathogenic variant in NLRP7 (19q13.42) associated with recurrent gestational trophoblastic disease: Data from early embryo development observed during in vitro fertilization. Clin. Exp. Reprod. Med. 2017, 44, 40-46. [CrossRef]

12. Abi Nahed, R.; Reynaud, D.; Borg, A.J.; Traboulsi, W.; Wetzel, A.; Sapin, V.; Brouillet, S.; Dieudonné, M.N.; Dakouane-Giudicelli, M.; Benharouga, M.; et al. NLRP7 is increased in human idiopathic fetal growth restriction and plays a critical role in trophoblast differentiation. J. Mol. Med. 2019, 97, 355-367. [CrossRef]

13. Alifrangis, C.; Agarwal, R.; Short, D.; Fisher, R.A.; Sebire, N.J.; Harvey, R.; Savage, P.M.; Seckl, M.J. EMA/CO for high-risk gestational trophoblastic neoplasia: Good outcomes with induction low-dose etoposide-cisplatin and genetic analysis. J. Clin. Oncol. 2013, 31, 280-286. [CrossRef]

14. Andersen, R.E.; Lim, D.A. Forging our understanding of lncRNAs in the brain. Cell Tissue Res. 2017, 371, 55-71. [CrossRef] [PubMed]

15. Isin, M.; Dalay, N. LncRNAs and neoplasia. Clin. Chim. Acta 2015, 444, 280-288. [CrossRef] [PubMed]

16. Yin, Y.; Yangyang, Z.; Lu, J.; Song, G.; Zhu, Y.; Li, Z.; Zhaohui, L.; Shen, B.; Huang, X.; Zhu, H.; et al. Opposing Roles for the lncRNA Haunt and Its Genomic Locus in Regulating HOXA Gene Activation during Embryonic Stem Cell Differentiation. Cell Stem Cell 2015, 16, 504-516. [CrossRef] [PubMed] 
17. Blokhin, I.; Khorkova, O.; Hsiao, J.; Wahlestedt, C. Developments in lncRNA drug discovery: Where are we heading? Expert Opin. Drug Discov. 2018, 13, 837-849. [CrossRef]

18. Guzel, E.; Okyay, T.M.; Yalcinkaya, B.; Karacaoglu, S.; Gocmen, M.; Akcakuyu, M.H. Tumor suppressor and oncogenic role of long non-coding RNAs in cancer. North Clin. Istanb. 2019, 7, 81-86. [CrossRef]

19. Gupta, R.A.; Shah, N.; Wang, K.C.; Kim, J.; Horlings, H.M.; Wong, D.J.; Tsai, M.C.; Hung, T.; Argani, P.; Rinn, J.L.; et al. Long non-coding RNA HOTAIR reprograms chromatin state to promote cancer metastasis. Nature 2010, 464, 1071-1076. [CrossRef] [PubMed]

20. Qiu, J.J.; Lin, Y.Y.; Ye, L.C.; Ding, J.X.; Feng, W.W.; Jin, H.Y.; Zhang, Y.; Li, Q.; Hua, K.Q. Overexpression of long non-coding RNA HOTAIR predicts poor patient prognosis and promotes tumor metastasis in epithelial ovarian cancer. Gynecol. Oncol. 2014, 134, 121-128. [CrossRef]

21. Huang, L.; Liao, L.M.; Liu, A.W.; Wu, J.B.; Cheng, X.L.; Lin, J.X.; Zheng, M. Overexpression of long noncoding RNA HOTAIR predicts a poor prognosis in patients with cervical cancer. Arch. Gynecol. Obstet. 2014, 290, 717-723. [CrossRef]

22. He, X.; Bao, W.; Li, X.; Chen, Z.; Che, Q.; Wang, H.; Wan, X.P. The long non-coding RNA HOTAIR is upregulated in endometrial carcinoma and correlates with poor prognosis. Int. J. Mol. Med. 2014, 33, 325-332. [CrossRef]

23. Kogo, R.; Shimamura, T.; Mimori, K.; Kawahara, K.; Imoto, S.; Sudo, T.; Tanaka, F.; Shibata, K.; Suzuki, A.; Komune, S.; et al. Long noncoding RNA HOTAIR regulates polycomb-dependent chromatin modification and is associated with poor prognosis in colorectal cancers. Cancer Res. 2011, 71, 6320-6326. [CrossRef]

24. Yang, Z.; Zhou, L.; Wu, L.M.; Lai, M.C.; Xie, H.Y.; Zhang, F.; Zheng, S.S. Overexpression of long non-coding RNA HOTAIR predicts tumor recurrence in hepatocellular carcinoma patients following liver transplantation. Ann. Surg. Oncol. 2011, 18, 1243-1250. [CrossRef] [PubMed]

25. Niinuma, T.; Suzuki, H.; Nojima, M.; Nosho, K.; Yamamoto, H.; Takamaru, H.; Yamamoto, E.; Maruyama, R.; Nobuoka, T.; Miyazaki, Y.; et al. Upregulation of miR-196a and HOTAIR drive malignant character in gastrointestinal stromal tumors. Cancer Res. 2012, 72, 1126-1136. [CrossRef] [PubMed]

26. Sheng, X.; Li, J.; Yang, L.; Chen, Z.; Zhao, Q.; Tan, L.; Zhou, Y.; Li, J. Promoter hypermethylation influences the suppressive role of maternally expressed 3, a long non-coding RNA, in the development of epithelial ovarian cancer. Oncol. Rep. 2014, 32, 277-285. [CrossRef]

27. Xiao, Y.; Pan, J.; Geng, Q.; Wang, G. Lnc RNA MALAT1 increases the stemness of gastric cancer cells via enhancing SOX2 mRNA stability. FEBS Open Biol. 2019, 9, 1212-1222. [CrossRef]

28. Jen, J.; Tang, Y.-A.; Lu, Y.-H.; Lin, C.-C.; Lai, W.-W.; Wang, Y.-C. Oct4 transcriptionally regulates the expression of long non-coding RNAs NEAT1 and MALAT1 to promote lung cancer progression. Mol. Cancer 2017, 16, 1-12. [CrossRef]

29. Shin, V.Y.; Chen, J.; Cheuk, I.W.-Y.; Siu, M.-T.; Ho, C.-W.; Wang, X.; Jin, H.; Kwong, A. Long non-coding RNA NEAT1 confers oncogenic role in triple-negative breast cancer through modulating chemoresistance and cancer stemness. Cell Death Dis. 2019, 10, 1-10. [CrossRef]

30. Jiang, P.; Chen, A.; Wu, X.; Zhou, M.; Haq, I.U.; Mariyam, Z.; Feng, Q. NEAT1 acts as an inducer of cancer stem cell-like phenotypes in NSCLC by inhibiting EGCG-upregulated CTR1. J. Cell. Physiol. 2018, 233, 4852-4863. [CrossRef]

31. Zang, J.; Zheng, M.; Cao, X.; Zhang, Y.; Zhang, Y.; Gao, X.; Cao, Y.; Shi, M.; Han, H.; Liang, L. Adenovirus infection promotes the formation of glioma stem cells from glioblastoma cells through the TLR9/NEAT1/STAT3 pathway. Cell Commun. Signal. 2020, 18, 135. [CrossRef]

32. Overholtzer, M.; Zhang, J.; Smolen, G.A.; Muir, B.; Li, W.; Sgroi, D.C.; Deng, C.-X.; Brugge, J.S.; Haber, D.A. Transforming properties of YAP, a candidate oncogene on the chromosome 11q22 amplicon. Proc. Natl. Acad. Sci. USA 2006, 103, 12405-12410. [CrossRef]

33. Zhang, Y.; Fang, Z.; Guo, X.; Dong, H.; Zhou, K.; Huang, Z.; Xiao, Z. IncRNA B4GALT1-AS1 promotes colon cancer cell stemness and migration by recruiting YAP to the nucleus and enhancing YAP transcriptional activity. J. Cell. Physiol. 2019, 234, 18524-18534. [CrossRef]

34. Gao, X.F.; He, H.Q.; Zhu, X.B.; Xie, S.L.; Cao, Y. LncRNA SNHG20 promotes tumorigenesis and cancer stemness in glioblastoma via activating PI3K/Akt/mTOR signaling pathway. Neoplasma 2019, 66, 532-542. [CrossRef]

35. Bolha, L.; Ravnik-Glavač, M.; Glavač, D. Long Noncoding RNAs as Biomarkers in Cancer. Dis. Markers 2017, $2017,7243968$. [CrossRef]

36. Hosseini, E.S.; Meryet-Figuiere, M.; Sabzalipoor, H.; Kashani, H.H.; Nikzad, H.; Asemi, Z. Dysregulated expression of long noncoding RNAs in gynecologic cancers. Mol. Cancer 2017, 16, 107. [CrossRef]

37. Tornesello, M.L.; Faraonio, R.; Buonaguro, L.; Annunziata, C.; Starita, N.; Cerasuolo, A.; Pezzuto, F.; Tornesello, A.L.; Buonaguro, F.M. The Role of microRNAs, Long Non-coding RNAs, and Circular RNAs in Cervical Cancer. Front. Oncol. 2020, 10, 150. [CrossRef]

38. Ma, L.; Bajic, V.B.; Zhang, Z. On the classification of long non-coding RNAs. RNA Biol. 2013, 10, 925-933. [CrossRef]

39. Hadjicharalambous, M.R.; Lindsay, M.A. Long Non-Coding RNAs and the Innate Immune Response. Noncoding RNA $2019,5,34$. [CrossRef] [PubMed]

40. Wang, D.Q.; Fu, P.; Yao, C.; Zhu, L.S.; Hou, T.Y.; Chen, J.G.; Lu, Y.; Liu, D.; Zhu, L.Q. Long Non-coding RNAs, Novel Culprits, or Bodyguards in Neurodegenerative Diseases. Mol. Ther. Nucleic Acids 2018, 10, 269-276. [CrossRef] 
41. Chellini, L.; Frezza, V.; Paronetto, M.P. Dissecting the transcriptional regulatory networks of promoter-associated noncoding RNAs in development and cancer. J. Exp. Clin. Cancer Res. 2020, 39, 51. [CrossRef]

42. Ernst, C.; Morton, C.C. Identification and function of long non-coding RNA. Front. Cell. Neurosci. 2013, 7, 168. [CrossRef]

43. Cabili, M.N.; Dunagin, M.C.; McClanahan, P.D.; Biaesch, A.; Padovan-Merhar, O.; Regev, A.; Rinn, J.L.; Raj, A. Localization and abundance analysis of human lncRNAs at single-cell and single-molecule resolution. Genome Biol. 2015, 16, e20. [CrossRef]

44. Hangauer, M.J.; Vaughn, I.W.; McManus, M.T. Pervasive Transcription of the Human Genome Produces Thousands of Previously Unidentified Long Intergenic Noncoding RNAs. PLoS Genet. 2013, 9, e1003569. [CrossRef]

45. Volders, P.J.; Anckaert, J.; Verheggen, K.; Nuytens, J.; Martens, L.; Mestdagh, P.; Vandesompele, J. Lncipedia 5: Towards a reference set of human long non-coding rnas. Nucleic Acids Res. 2019, 47, D135-D139. [CrossRef]

46. Yao, R.W.; Wang, Y.; Chen, L.L. Cellular functions of long noncoding RNAs. Nat. Cell Biol. 2019, 21, 542-551. [CrossRef]

47. Pontier, D.B.; Gribnau, J. Xist regulation and function explored. Hum. Genet. 2011, 130, 223-236. [CrossRef]

48. Żylicz, J.J.; Bousard, A.; Žumer, K.; Dossin, F.; Mohammad, E.; da Rocha, S.T.; Schwalb, B.; Syx, L.; Dingli, F.; Loew, D.; et al. The Implication of Early Chromatin Changes in X Chromosome Inactivation. Cell 2019, 176, 182-197.e23. [CrossRef]

49. Puvvula, P.K.; Desetty, R.D.; Pineau, P.; Marchio, A.; Moon, A.; Dejean, A.; Bischof, O. Long noncoding RNA PANDA and scaffold-attachment-factor SAFA control senescence entry and exit. Nat. Commun. 2014, 5, 5323. [CrossRef]

50. Li, Z.; Li, Y.; Li, Y.; Ren, K.; Li, X.; Han, X.; Wang, J. Long non-coding RNA H19 promotes the proliferation and invasion of breast cancer through upregulating DNMT1 expression by sponging miR-152. J. Biochem. Mol. Toxicol. 2017, 31, e21933. [CrossRef] [PubMed]

51. Liu, L.; Yang, J.; Zhu, X.; Li, D.; Lv, Z.; Zhang, X. Long noncoding RNA H19 competitively binds miR-17-5p to regulate YES1 expression in thyroid cancer. FEBS J. 2016, 283, 2326-2339. [CrossRef] [PubMed]

52. Mondal, T.; Subhash, S.; Vaid, R.; Enroth, S.; Uday, S.; Reinius, B.; Mitra, S.; Mohammed, A.; James, A.R.; Hoberg, E.; et al. Author Correction: MEG3 long noncoding RNA regulates the TGF- $\beta$ pathway genes through formation of RNA-DNA triplex structures. Nat. Commun. 2019, 10, 5290. [CrossRef] [PubMed]

53. Zappulla, D.C.; Cech, T.R. Yeast telomerase RNA: A flexible scaffold for protein subunits. Proc. Natl. Acad. Sci. USA 2004, 101, 10024-10029. [CrossRef] [PubMed]

54. Rinn, J.L.; Kertesz, M.; Wang, J.K.; Squazzo, S.L.; Xu, X.; Brugmann, S.A.; Goodnough, L.H.; Helms, J.A.; Farnham, P.J.; Segal, E.; et al. Functional demarcation of active and silent chromatin domains in human HOX loci by noncoding RNAs. Cell 2007, 129, 1311-1323. [CrossRef]

55. Patty, B.J.; Hainer, S.J. Non-Coding RNAs and Nucleosome Remodeling Complexes: An Intricate Regulatory Relationship. Biology 2020, 9, 213. [CrossRef]

56. Ayers, D.; Vandesompele, J. Influence of microRNAs and Long Non-Coding RNAs in Cancer Chemoresistance. Genes 2017, 8, 95. [CrossRef]

57. Grixti, J.M.; Ayers, D. Long noncoding RNAs and their link to cancer. Noncoding RNA Res. 2020, 5, 77-82. [CrossRef]

58. Fang, Y.; Fullwood, M.J. Roles, Functions, and Mechanisms of Long Non-coding RNAs in Cancer. Genom. Proteom. Bioinform. 2016, 14, 42-54. [CrossRef]

59. Carlevaro-Fita, J.; Lanzós, A.; Feuerbach, L.; Hong, C.; Mas-Ponte, D.; Pedersen, J.S. PCAWG Drivers and Functional Interpretation Group, Johnson R.; PCAWG Consortium. Cancer LncRNA Census reveals evidence for deep functional conservation of long noncoding RNAs in tumorigenesis. Commun. Biol. 2020, 3, 56. [CrossRef]

60. Shi, D.; Zhang, Y.; Lu, R.; Zhang, Y. The long non-coding RNA MALAT1 interacted with miR-218 modulates choriocarcinoma growth by targeting Fbxw8. Biomed. Pharmacother. 2018, 97, 543-550. [CrossRef]

61. Yu, S.; Wu, C.; Tan, Q.; Liu, H. Long noncoding RNA H19 promotes chemotherapy resistance in choriocarcinoma cells. J. Cell. Biochem. 2019, 120, 15131-15144. [CrossRef]

62. Wake, N.; Arima, T.; Matsuda, T. Involvement of IGF2 and H19 imprinting in choriocarcinoma development. Int. J. Gynaecol. Obstet. 1998, 60, S1-S8. [CrossRef]

63. Zhang, Y.; Zou, Y.; Wang, W.; Zuo, Q.; Jiang, Z.; Sun, M.; De, W.; Sun, L. Down-regulated long non-coding RNA MEG3 and its effect on promoting apoptosis and suppressing migration of trophoblast cells. J. Cell. Biochem. 2015, 116, 542-550. [CrossRef]

64. Wang, Y.N.; Liu, S.Y.; Wang, L.; Han, L.Y. Long noncoding RNA PCA3 contributes to the progression of choriocarcinoma by acting as a ceRNA against miR-106b. Int. J. Clin. Exp. Pathol. 2019, 12, 1609-1617. [PubMed]

65. Wang, Y.; Xue, K.; Guan, Y.; Jin, Y.; Liu, S.; Wang, Y.; Liu, S.; Wang, L.; Han, L. Long Noncoding RNA LINC00261 Suppresses Cell Proliferation and Invasion and Promotes Cell Apoptosis in Human Choriocarcinoma. Oncol. Res. 2017, 25, 733-742. [CrossRef]

66. Meng, Q.; Xue, H. Knockdown of lncRNA OGFRP1 Inhibits Proliferation and Invasion of JEG-3 Cells Via AKT/mTOR Pathway. Technol. Cancer Res. Treat. 2020, 19, 1533033820905823. [CrossRef]

67. Muys, B.R.; Lorenzi, J.C.; Zanette, D.L.; Lima e Bueno Rde, B.; de Araújo, L.F.; Dinarte-Santos, A.R.; Alves, C.P.; Ramão, A.; de Molfetta, G.A.; Vidal, D.O.; et al. Placenta-Enriched LincRNAs MIR503HG and LINC00629 Decrease Migration and Invasion Potential of JEG-3 Cell Line. PLoS ONE 2016, 11, e0151560. [CrossRef]

68. Wu, Y.; Huang, C.; Meng, X.; Li, J. Long Noncoding RNA MALAT1: Insights into its Biogenesis and Implications in Human Disease. Curr. Pharm. Des. 2015, 21, 5017-5028. [CrossRef] [PubMed]

69. Yoshimoto, R.; Mayeda, A.; Yoshida, M.; Nakagawa, S. MALAT1 long non-coding RNA in cancer. Biochim. Biophys. Acta 2016, 1859, 192-199. [CrossRef] 
70. Ji, P.; Diederichs, S.; Wang, W.; Böing, S.; Metzger, R.; Schneider, P.M.; Tidow, N.; Brandt, B.; Buerger, H.; Bulk, E.; et al. MALAT-1, a novel noncoding RNA, and thymosin $\beta 4$ predict metastasis and survival in early-stage non-small cell lung cancer. Oncogene 2003, 22, 8031-8041. [CrossRef]

71. Lin, R.; Roychowdhury-Saha, M.; Black, C.; Watt, A.T.; Marcusson, E.G.; Freier, S.M.; Edgington, T.S. Control of RNA processing by a large non-coding RNA overexpressed in carcinomas. FEBS Lett. 2011, 585, 671-676. [CrossRef]

72. Gutschner, T.; Hämmerle, M.; Diederichs, S. MALAT1-A paradigm for long noncoding RNA function in cancer. J. Mol. Med. 2013, 91, 791-801. [CrossRef]

73. Smits, G.; Mungall, A.J.; Griffiths-Jones, S.; Smith, P.; Beury, D.; Matthews, L.; Rogers, J.; Pask, A.J.; Shaw, G.; VandeBerg, J.L.; et al. Conservation of the H19 noncoding RNA and H19-IGF2 imprinting mechanism in therians. Nat. Genet. 2008, 40, 971-976. [CrossRef]

74. Jing, W.; Zhu, M.; Zhang, X.W.; Pan, Z.Y.; Gao, S.S.; Zhou, H.; Qiu, S.L.; Liang, C.Z.; Tu, J.C. The Significance of Long Noncoding RNA H19 in Predicting Progression and Metastasis of Cancers: A Meta-Analysis. Biomed. Res. Int. 2016, 2016, 5902678. [CrossRef]

75. Ariel, I.; Miao, H.Q.; Ji, X.R.; Schneider, T.; Roll, D.; de Groot, N.; Hochberg, A.; Ayesh, S. Imprinted H19 oncofetal RNA is a candidate tumour marker for hepatocellular carcinoma. Mol. Pathol. 1998, 51, 21-25. [CrossRef] [PubMed]

76. Hao, Y.; Crenshaw, T.; Moulton, T.; Newcomb, E.; Tycko, B. Tumour-suppressor activity of H19 RNA. Nature 1993, 365, 764-767. [CrossRef]

77. Kondo, M.; Suzuki, H.; Ueda, R.; Osada, H.; Takagi, K.; Takahashi, T.; Takahashi, T. Frequent loss of imprinting of the H19 gene is often associated with its overexpression in human lung cancers. Oncogene 1995, 10, 1193-1198. [PubMed]

78. Cooper, M.J.; Fischer, M.; Komitowski, D.; Shevelev, A.; Schulze, E.; Ariel, I.; Tykocinski, M.L.; Miron, S.; Ilan, J.; de Groot, N.; et al. Developmentally imprinted genes as markers for bladder tumor progression. J. Urol. 1996, 155, 2120-2127. [CrossRef]

79. Schwarzenbach, H. Biological and Clinical Relevance of H19 in Colorectal Cancer Patients. EBioMedicine 2016, 13, 9-10. [CrossRef]

80. Tselepis, C.; Chidgey, M.; North, A.; Garrod, D. Desmosomal adhesion inhibits invasive behavior. Proc. Natl. Acad. Sci. USA 1998, 95, 8064-8069. [CrossRef]

81. Benetatos, L.; Vartholomatos, G.; Hatzimichael, E. MEG3 imprinted gene contribution in tumorigenesis. Int. J. Cancer 2011, 129, 773-779. [CrossRef]

82. Zhang, J.; Yao, T.; Wang, Y.; Yu, J.; Liu, Y.; Lin, Z. Long noncoding RNA MEG3 is downregulated in cervical cancer and affects cell proliferation and apoptosis by regulating miR-21. Cancer Biol. Ther. 2016, 17, 104-113. [CrossRef]

83. Clarke, R.A.; Zhao, Z.; Guo, A.Y.; Roper, K.; Teng, L.; Fang, Z.M.; Samaratunga, H.; Lavin, M.F.; Gardiner, R. A: New genomic structure for prostate cancer specific gene PCA3 within BMCC1: Implications for prostate cancer detection and progression. PLoS ONE 2009, 4, e4995. [CrossRef]

84. Hanze, J.; Jakubowski, P.; Heers, H.; Hegele, A.; Timmesfeld, N.; Hofmann, R.; Olbert, P.J. Assessing blood platelets as RNA biomarker source for prostate cancer. Biomarkers 2016, 21, 653-659. [CrossRef] [PubMed]

85. Feibus, A.H.; Sartor, O.; Moparty, K.; Chagin, K.; Kattan, M.W.; Ledet, E.; Levy, J.; Lee, B.; Thomas, R.; Silberstein, J.L. Clinical use of PCA3 and TMPRSS2: ERG urinary biomarkers in African-American Men undergoing prostate biopsy. J. Urol. 2016, 196, 1053-1060. [CrossRef] [PubMed]

86. Zheng, K.; Dou, Y.; He, L.; Li, H.; Zhang, Z.; Chen, Y.; Ye, A.; Liu, W.; Kong, L. Improved sensitivity and specificity for prostate cancer diagnosis based on the urine PCA3/PSA ratio acquired by sequence specific RNA capture. Oncol. Rep. 2015, 34, $2439-2444$. [CrossRef] [PubMed]

87. Salameh, A.; Lee, A.K.; Cardo-Vila, M.; Nunes, D.N.; Efstathiou, E.; Staquicini, F.I.; Dobroff, A.S.; Marchio, S.; Navone, N.M.; Hosoya, H.; et al. PRUNE2 is a human prostate cancer suppressor regulated by the intronic long noncoding RNA PCA3. Proc. Natl. Acad. Sci. USA 2015, 112, 8403-8408. [CrossRef] [PubMed]

88. Quek, S.I.; Wong, O.M.; Chen, A.; Borges, G.T.; Ellis, W.J.; Salvanha, D.M.; Vencio, R.Z.; Weaver, B.; Ench, Y.M.; Leach, R.J.; et al. Processing of voided urine for prostate cancer RNA biomarker analysis. Prostate 2015, 75, 1886-1895. [CrossRef]

89. Cao, W.J.; Wu, H.L.; He, B.S.; Zhang, Y.S.; Zhang, Z.Y. Analysis of long non-coding RNA expression profiles in gastric cancer. World J. Gastroenterol. 2013, 19, 3658-3664. [CrossRef]

90. Muller, S.; Raulefs, S.; Bruns, P.; Afonso-Grunz, F.; Plotner, A.; Thermann, R.; Jager, C.; Schlitter, A.M.; Kong, B.; Regel, I.; et al. Next-generation sequencing reveals novel differentially regulated mRNAs, lncRNAs, miRNAs, sdRNAs and a piRNA in pancreatic cancer. Mol. Cancer 2015, 14, 94.

91. Yu, Y.; Li, L.; Zheng, Z.; Chen, S.; Chen, E.; Hu, Y. Long non-coding RNA linc00261 suppresses gastric cancer progression via promoting slug degradation. J. Cell. Mol. Med. 2017, 21, 955-967. [CrossRef] [PubMed]

92. Shi, J.; Ma, H.; Wang, H.; Zhu, W.; Jiang, S.; Dou, R.; Yan, B. Overexpression of LINC00261 inhibits non-small cell lung cancer cells progression by interacting with miR-522-3p and suppressing Wnt signaling. J. Cell. Biochem. 2019, 120, 18378-18387. [CrossRef] [PubMed]

93. Yan, D.; Liu, W.; Liu, Y.; Luo, M. LINC00261 suppresses human colon cancer progression via sponging miR-324-3p and inactivating the Wnt/beta-catenin pathway. J.Cell. Physiol. 2019, 234, 22648-22656. [CrossRef] [PubMed]

94. Zhang, X.; Liu, J.; Gu, Y.; Sun, C.; Qu, F. Down-regulation of lncRNA OGFRP1 induces autophagy and growth inhibition by AKT/mTOR signaling pathway in HCAECs. Cell Biol. Int. 2019, 43, 158-166. [CrossRef]

95. Chen, W.; You, J.; Zheng, Q.; Zhu, Y.Y. Downregulation of lncRNA OGFRP1 inhibits hepatocellular carcinoma progression by $\mathrm{AKT} / \mathrm{mTOR}$ and Wnt/beta-catenin signaling pathways. Cancer Manag. Res. 2018, 10, 1817-1826. [CrossRef] 
96. Zou, K.; Yu, H.; Chen, X.; Ma, Q.; Hou, L. Silencing long noncoding RNA OGFRP1 inhibits the proliferation and migration of cervical carcinoma cells. Cell Biochem. Funct. 2019, 37, 591-597. [CrossRef]

97. Fant, M.; Farina, A.; Nagaraja, R.; Schlessinger, D. PLAC1 (placenta specific 1): A novel, X-linked gene with roles in reproductive and cancer biology. Prenat. Diag. 2010, 30, 497-502. [CrossRef]

98. Jackman, S.M.; Kong, X.; Fant, M.E. Plac1 (Placenta-specific 1) is essential for normal placental and embryonic development. Mol. Reprod. Dev. 2012, 79, 564-572. [CrossRef]

99. Zhang, Y.; Tao, Y.; Li, Y.; Zhao, J.; Zhang, L.; Zhang, X.; Dong, C.; Xie, Y.; Dai, X.; Zhang, X.; et al. The regulatory network analysis of long noncoding RNAs in human colorectal cancer. Funct. Integr. Genom. 2018, 18, 261-275. [CrossRef]

100. Chung, I.H.; Lu, P.H.; Lin, Y.H.; Tsai, M.M.; Lin, Y.W.; Yeh, C.T.; Lin, K.H. The long non-coding RNA LINC01013 enhances invasion of human anaplastic large-cell lymphoma. Sci. Rep. 2017, 7, 295. [CrossRef]

101. Wang, H.; Liang, L.; Dong, Q.; Huan, L.; He, J.; Li, B.; Yang, C.; Jin, H.; Wei, L.; Yu, C.; et al. Long noncoding RNA miR503HG, a prognostic indicator, inhibits tumor metastasis by regulating the HNRNPA2B1/NF-kappaB pathway in hepatocellular carcinoma. Theranostics 2018, 8, 2814-2829. [CrossRef]

102. Nakamura, K.; Akiba, J.; Ogasawara, S.; Naito, Y.; Nakayama, M.; Abe, Y.; Kusukawa, J.; Yano, H. SUOX is negatively associated with multistep carcinogenesis and proliferation in oral squamous cell carcinoma. Med. Mol. Morphol. 2018, 51, 102-110. [CrossRef]

103. Fu, J.; Dong, G.; Shi, H.; Zhang, J.; Ning, Z.; Bao, X.; Liu, C.; Hu, J.; Liu, M.; Xiong, B. LncRNA MIR503HG inhibits cell migration and invasion via miR-103/OLFM4 axis in triple negative breast cancer. J. Cell. Mol. Med. 2019, 23, 4738-4745. [CrossRef]

104. Li, J.; Wang, L.; He, F.; Li, B.; Han, R. Long noncoding RNA LINC00629 restrains the progression of gastric cancer by upregulating AQP4 through competitively binding to miR-196b-5p. J. Cell. Physiol. 2020, 235, 2973-2985. [CrossRef] [PubMed]

105. Xu, M.D.; Qi, P.; Du, X. Long non-coding RNAs in colorectal cancer: Implications for pathogenesis and clinical application. Mod. Pathol. 2014, 27, 1310-1320. [CrossRef] [PubMed]

106. Traboulsi, W.; Sergent, F.; Boufettal, H.; Brouillet, S.; Slim, R.; Hoffmann, P.; Benlahfid, M.; Zhou, Q.Y.; Balboni, G.; Onnis, V. Antagonism of EG-VEGF Receptors as Targeted Therapy for Choriocarcinoma Progression In Vitro and In Vivo. Clin. Cancer Res. 2017, 23, 7130-7140. [CrossRef] [PubMed]

107. Kishikawa, T.; Otsuka, M.; Ohno, M.; Yoshikawa, T.; Takata, A.; Koike, K. Circulating RNAs as new biomarkers for detecting pancreatic cancer. World J. Gastroenterol. 2015, 21, 8527-8540. [CrossRef]

108. Ebert, M.S.; Sharp, P.A. MicroRNA sponges: Progress and possibilities. RNA 2010, 16, 2043-2050. [CrossRef]

109. Arun, G.; Diermeier, S.D.; Spector, D.L. Therapeutic Targeting of Long Non-Coding RNAs in Cancer. Trends Mol. Med. 2018, 24, 257-277. [CrossRef]

110. Schwarzmueller, L.; Bril, O.; Vermeulen, L.; Léveillé, N. Emerging Role and Therapeutic Potential of lncRNAs in Colorectal Cancer. Cancers 2020, 12, 3843. [CrossRef]

111. Borel, F.; Kay, M.A.; Mueller, C. Recombinant AAV as a platform for translating the therapeutic potential of RNA interference. Mol. Ther. 2014, 22, 692-701. [CrossRef]

112. Adams, D.; Gonzalez-Duarte, A.; O’Riordan, W.D.; Yang, C.C.; Ueda, M.; Kristen, A.V.; Tournev, I.; Schmidt, H.H.; Coelho, T.; Berk, J.L.; et al. Patisiran, an RNAi Therapeutic, for Hereditary Transthyretin Amyloidosis. N. Engl. J. Med. 2018, 379, 11-21. [CrossRef]

113. Eckstein, F. Phosphorothioate oligodeoxynucleotides: What is their origin and what is unique about them? Antisense Nucleic Acid Drug Dev. 2000, 10, 117-121. [CrossRef]

114. Kraynack, B.A.; Baker, B.F. Small interfering RNAs containing full 2'-O-methylribonucleotide-modified sense strands display Argonaute2/eIF2C2-dependent activity. RNA 2006, 12, 163-176. [CrossRef] [PubMed]

115. Walder, R.Y.; Walder, J.A. Role of RNase H in hybrid-arrested translation by antisense oligonucleotides. Proc. Natl. Acad. Sci. USA 1988, 85, 5011-5015. [CrossRef] [PubMed]

116. Chiriboga, C.A. Nusinersen for the treatment of spinal muscular atrophy. Expert Rev. Neurother. 2017, 17, 955-962. [CrossRef] [PubMed]

117. Jaschinski, F.; Rothhammer, T.; Jachimczak, P.; Seitz, C.; Schneider, A.; Schlingensiepen, K.H. The antisense oligonucleotide trabedersen (AP12009) for the targeted inhibition of TGF-beta2. Curr. Pharm. Biotechnol. 2011, 12, 2203-2213. [CrossRef]

118. Brezgin, S.; Kostyusheva, A.; Kostyushev, D.; Chulanov, V. Dead Cas Systems: Types, Principles, and Applications. Int. J. Mol. Sci. 2019, 20, 6041. [CrossRef]

119. Liu, S.J.; Horlbeck, M.A.; Cho, S.W. CRISPRi-based genome-scale identification of functional long noncoding RNA loci in human cells. Science 2017, 355. [CrossRef]

120. Ates, I.; Rathbone, T.; Stuart, C.; Bridges, P.H.; Cottle, R.N. Delivery approaches for therapeutic genome editing and challenges. Genes 2020, 11, 1113. [CrossRef]

121. Lino, C.A.; Harper, J.C.; Carney, J.P.; Timlin, J.A. Delivering crispr: A review of the challenges and approaches. Drug Deliv. 2018, 25, 1234-1257. [CrossRef]

122. Witzigmann, D.; Kulkarni, J.A.; Leung, J.; Chen, S.; Cullis, P.R.; van der Meel, R. Lipid nanoparticle technology for therapeutic gene regulation in the liver. Adv. Drug Deliv. Rev. 2020, 159, 344-363. [CrossRef]

123. Abudayyeh, O.O.; Gootenberg, J.S.; Essletzbichler, P.; Han, S.; Joung, J.; Belanto, J.J.; Verdine, V.; Cox, D.B.T.; Kellner, M.J.; Regev, A.; et al. RNA targeting with CRISPR-Cas13. Nature 2017, 550, 280-284. [CrossRef] 
124. Gilbert, L.A.; Horlbeck, M.A.; Adamson, B.; Villalta, J.E.; Chen, Y.; Whitehead, E.H.; Guimaraes, C.; Panning, B.; Ploegh, H.L.; Bassik, M.C.; et al. Genome-scale CRISPR-mediated control of gene repression and activation. Cell 2014, 159, 647-661. [CrossRef]

125. Hazafa, A.; Mumtaz, M.; Farooq, M.F.; Bilal, S.; Chaudhry, S.N.; Firdous, M.; Naeem, H.; Ullah, M.O.; Yameen, M.; Mukhtiar, M.S.; et al. CRISPR/Cas9: A powerful genome editing technique for the treatment of cancer cells with present challenges and future directions. Life Sci. 2020, 263, 118525. [CrossRef]

126. Hirakawa, M.P.; Krishnakumar, R.; Timlin, J.A.; Carney, J.P.; Butler, K.S. Gene editing and CRISPR in the clinic: Current and future perspectives. Biosci. Rep. 2020, 40, BSR20200127. [CrossRef]

127. Xu, D.; Cai, Y.; Tang, L.; Han, X.; Gao, F.; Cao, H.; Qi, F.; Kapranov, P. A CRISPR/Cas13-based approach demonstrates biological relevance of vlinc class of long non-coding RNAs in anticancer drug response. Sci. Rep. 2020, 10, 1794. [CrossRef] 